\title{
Clinicopathologic Presentation and Management of Malignant Orbito-ocular Tumors at a Tertiary Care Hospital in Nepal
}

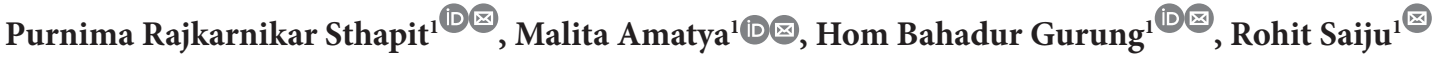 \\ ${ }^{1}$ Tilganga Institute of Ophthalmology, Gaushala, Kathmandu, Nepal
}

\begin{abstract}
Introduction: This study was conducted to evaluate the clinical presentations and management of various Orbito-ocular malignancies in Nepal.

Materials and methods: This is a prospective study of ocular malignant cases conducted at a tertiary care eye hospital in Kathmandu, Nepal. One hundred and seventeen newly diagnosed eyes with ocular malignancy of 106 patients presenting to the clinic in a year from September 2018 to August 2019 were included for analysis. Patients' demography, clinical features, various types of malignancies seen in eyes and their management were evaluated.
\end{abstract}

Results: The mean age of patients was 30.35 years with a range from 1 month to 84 years and standard deviation of 26.63 . $56 \%$ of the total were male. Red eyes and visible mass were the most common symptoms in $23 \%$ with intraocular contents in $48 \%$ being the most common site involved. Different types of ocular malignancies were detected, among which retinoblastoma was the most common in $38 \%$ of patients. Diagnosis in most patients was clinical and/or radiological; incision biopsy was required in $1.7 \%$ patients only. Surgical excision of the tumor was the most common treatment done in $29 \%$ followed by enucleation in $27 \%$ of eyes. Bilateral involvement of the eyes was seen in $10 \%$ of the patients.

Conclusion: Malignant orbito-ocular tumors can be seen in any age group. Retinoblastoma is the commonest malignancy seen. With the help of imaging, diagnosis is near accurate; hence biopsy is not required in most cases before commencing treatment.

Key words: Malignant intraocular tumors, Malignant orbital tumors, Orbital metastasis, Retinoblastoma.

\section{INTRODUCTION}

Malignant tumors of the eye and periocular tissue are not so common but an important group of disorders present in all age groups. They may originate primarily from the ocular tissues like choroid, meibomian glands or lacrimal glands etc. or due to invasion from nearby structures

$\begin{array}{ll}\text { Financial Interest } \quad \text { Nil } & \text { Received : } 07.11 .2020 \\ \text { Conflict of Interest : Nil } & \text { Accepted : } 02.03 .2021 \\ \text { Corresponding Author } & \\ \text { Dr. Purnima Rajkarnikar Sthapit } & \\ \text { Department of Oculoplasty and Ocular oncology, } \\ \text { Tilganga Institute of Ophthalmology, } \\ \text { Gaushala, Kathmandu, Nepal. } \\ \text { E-mail: purnimark@gmail.com } \\ \text { Contact: +977 9813254962 }\end{array}$

Access this article online

Website: www.nepjol.info/index.php/NEPJOPH DOI: https://doi.org/10.3126/nepjoph.v13i2.32865 Copyright $\odot 2021$ Nepal Ophthalmic Society ISSN: 2072-6805, E-ISSN: 2091-0320

This work is licensed under a Creative Commons Attribution-NonCommercial-NoDerivatives 4.0 International License (CC BY-NC-ND). 
like paranasal sinuses, nasopharynx or cranial cavity. They may also present as infiltration from systemic malignancies like lymphoma or as a distant metastasis from malignant tumors elsewhere in the body.

Different types of malignant ocular tumors show racial and geographical variation as reported by various authors. A study in eyelid cancers carried out in India by Kalki et al in 2019 showed that sebaceous gland carcinoma was the most common malignant eyelid tumor (Seb gland Ca) in 53\% followed by basal cell carcinoma (BCC) in $24 \%$ while it is well known that $\mathrm{BCC}$ is most common in western world having fair skin people $(85 \%)$ cases as reported by Margo (1993). Another notable geographical variant is seen in uveal melanoma which is seen as the most common intraocular malignancy in Europe and America while it is not that common in our parts of the world (Koopman et al, 2011; Lee et al, 2000).

In neighboring countries like Singapore, India and Philippines, it was found that retinoblastomas (RB) are far more common than uveal melanomas and they comprise more than half of reported eye cancer cases (Lee et al, 2000; Gupta et al, 2017; Domingo et al, 2015).

The main objective of our study is to find out the relative frequencies, age and sex distribution of various malignant ocular and adnexal tumors and compare their geographical variation within Nepal and elsewhere. This can help to determine the trend of these tumors in Nepal since very few papers regarding this topic have been published from Nepal and most of them are in RB only. However, ocular surface cancers, melanomas, lacrimal gland cancers and metastatic eye cancers are also commonly seen in our daily practice in the ocular oncology clinic. This basic information can be useful for ophthalmologists and oncologists to keep ocular malignancy as an important differential diagnosis since it can be not only vision but life threatening as well.

\section{MATERIALS AND METHODS}

It is a prospective, non-comparative study of ocular malignancy cases seen at Ocular oncology and Oculoplasty department of Tilganga Institute of Ophthalmology (TIO), Kathmandu, Nepal. All consecutive new ocular malignancy case records presented from September 2018 to August 2019 were included in the study.

The suspected cases of ocular malignancies were mostly referred from other departments of TIO as well as from other hospitals around Nepal and bordering cities of India. All types of primary ocular malignancies arising from eyelid, conjunctiva, intraocular structures, orbital contents, secondary orbital malignancies from adjoining paranasal sinuses and brain, invasion of ocular structures from systemic malignancies as well as distant metastasis to eye and orbit were included in the study. Benign tumors of the eye and adnexa were excluded from the study. Demographic data collected included age, sex, presenting symptoms, geographic distribution and laterality. Patient's data along with clinical photographs, fundus photographs, 
histopathology reports (where available) and Computed Tomography (CT scan), Magnetic Resonance Imaging (MRI scan) results were recorded.

Imaging and histopathology reports of the primary site were recorded in cases of distant metastasis and systemic malignancies. Results of metastatic workup were collected wherever indicated. The clinical data were analyzed with regard to the demographic data, types of primary, secondary and metastatic ocular malignancies, ocular structures involved, and treatment done by ocular and medical oncologists.

Informed consent has been taken from the patients for the study as well as for medical and surgical management. Consent has also been taken for the photographic documentation. Ethical approval was taken from the Institutional Review Board of TIO.

\section{RESULTS}

During the study period, a total of 117 eyes of 106 patients who had malignancy in eye and adnexa from various origins were recorded. The mean patient age at the time of presentation was 30.35 years (range, 1 month to 84 years; SD 26.63). There were $59(56 \%)$ male and $47(44 \%)$ female patients. Eleven of our patients were from India while the rest are from different districts all over Nepal. There is no significant geographical variation in the distribution of malignant ocular tumors where people from mountains, hills and terai regions are almost equal in number. The higher number of patients from Kathmandu (29 patients, 27.4\%) is because of the location of our hospital in the same city and it being a densely populated region of Nepal.

Of the 106 patients, $11(10 \%)$ had bilateral disease. Patients presented most commonly with red eye and mass lesions (23\% each). Clinical presentations are illustrated in Figure 1. Regarding distribution of malignant ocular lesions, tumors arising from intraocular structures were the most common in 56 eyes (47\%) as shown in Table 1. Among them, retinoblastoma in $38 \%$ was the most common intraocular and overall most commonly seen malignant ocular condition in our study (Figure 2). It was followed by ocular surface squamous neoplasia (OSSN) in 32\% eyes (Figure 3) and ocular metastasis from distant (Figure 4) sites in $11 \%$ eyes. Rest of the types of ocular malignancies are compared and summarized in Table 2.

Due to various types of malignancies arising from different ocular structures, their management also varied. Surgery was the most common treatment done in $29.06 \%$ followed by combined (surgical and medical) and medical treatment alone in $23.93 \%$ of eyes. Six patients during the course of evaluation or treatment were lost to follow-up. Rest of the patient's management is summarized in Table 3. Among the patients who underwent surgery, excision of the tumor was the most common surgery performed in $29.91 \%$ of eyes, rest is given in Table 4.

In all, $11 \%$ of patients were found to have regional metastasis and $9 \%$ had distant metastasis. Rest of the $79 \%$ patients had malignancy localized to eye or orbit only. 
Table 1: Common sites involved by Orbito-ocular malignancy.

\begin{tabular}{|l|c|c|}
\hline \multicolumn{1}{|c|}{ Site of the lesion } & Number of eyes & Percentage \\
\hline Intraocular & 56 & $47.86 \%$ \\
\hline Conjunctiva & 38 & $32.48 \%$ \\
\hline Orbit & 13 & $11.11 \%$ \\
\hline Lid & 7 & $5.98 \%$ \\
\hline Optic nerve & 3 & $2.56 \%$ \\
\hline Total & 117 & \\
\hline
\end{tabular}

Table 2: Types of Orbito-ocular malignant tumors as per Histopathology.

\begin{tabular}{|l|c|c|}
\hline \multicolumn{1}{|c|}{ Diagnosis } & Number of eyes & Percentage \\
\hline Retinoblastoma & 45 & $38.46 \%$ \\
\hline OSSN & 37 & $31.62 \%$ \\
\hline Metastasis to Eye & 13 & $11.11 \%$ \\
\hline Uveal melanoma & 10 & $8.55 \%$ \\
\hline Basal cell carcinoma & 4 & $3.42 \%$ \\
\hline Lacrimal gland malignancy & 3 & $2.56 \%$ \\
\hline Malignant Melanoma Conjunctiva & 1 & $0.85 \%$ \\
\hline Malignant Melanoma Orbit & 1 & $0.85 \%$ \\
\hline Optic Disc Melanoma & 1 & $0.85 \%$ \\
\hline Sebaceous gland carcinoma & 1 & $0.85 \%$ \\
\hline Squamous cell carcinoma & 1 & $0.85 \%$ \\
\hline Total & 117 & $100.00 \%$ \\
\hline
\end{tabular}

Table 3: Modes of treatment of orbito-ocular malignancy.

\begin{tabular}{|l|c|c|}
\hline \multicolumn{1}{|c|}{ Mode of treatment } & Number of eyes & Percentage \\
\hline Medical & 28 & $23.93 \%$ \\
\hline Surgical & 34 & $29.06 \%$ \\
\hline Medical + Surgical & 28 & $23.93 \%$ \\
\hline Plaque brachytherapy & 1 & $0.85 \%$ \\
\hline EBRT & 1 & $0.85 \%$ \\
\hline Palliative & 2 & $1.70 \%$ \\
\hline Loss to follow up & 6 & $5.13 \%$ \\
\hline Medical + EBRT & 2 & $1.71 \%$ \\
\hline Surgical + EBRT & 5 & $4.27 \%$ \\
\hline Medical + Surgical + EBRT & 9 & $7.69 \%$ \\
\hline Surgical + Plaque therapy & 1 & $0.85 \%$ \\
\hline Total & 117 & $100.00 \%$ \\
\hline
\end{tabular}


Table 4: Types of surgical procedures performed in 76 eyes with malignant orbito-ocular tumors.

\begin{tabular}{|l|c|c|}
\hline \multicolumn{1}{|c|}{ Type of surgical Management } & Number of eyes & Percentage \\
\hline Excision of tumor & 35 & $29.91 \%$ \\
\hline Enucleation & 32 & $27.35 \%$ \\
\hline Exenteration & 7 & $5.98 \%$ \\
\hline Incisional biopsy & 2 & $1.71 \%$ \\
\hline
\end{tabular}

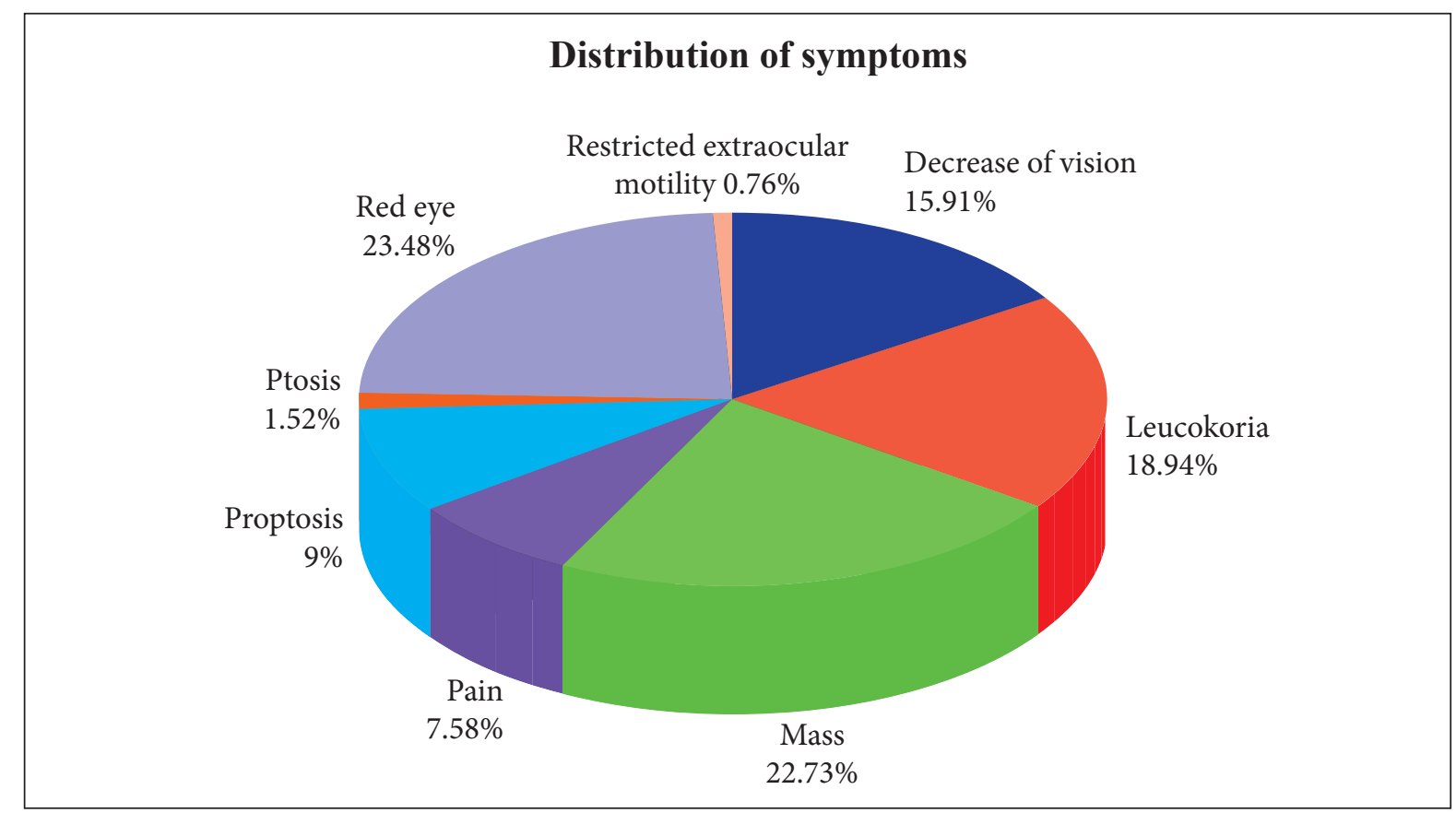

Figure 1: Clinical presentations in the patients with malignant orbito-ocular tumors

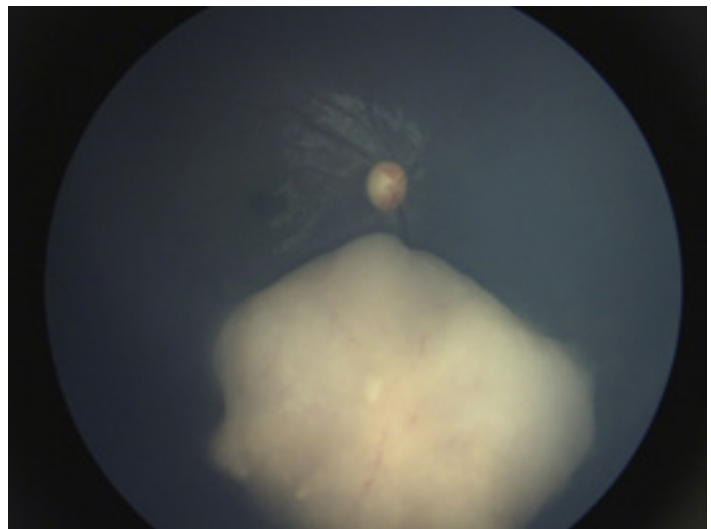

Figure 2: ICRB Group C retinoblastoma tumor with minimal subretinal fluid and seeds.

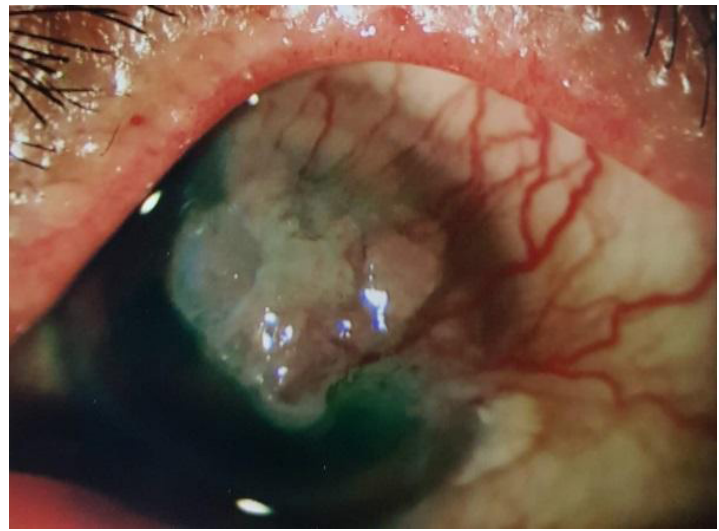

Figure 3: OSSN conjunctivo-corneal squamous cell carcinoma. 


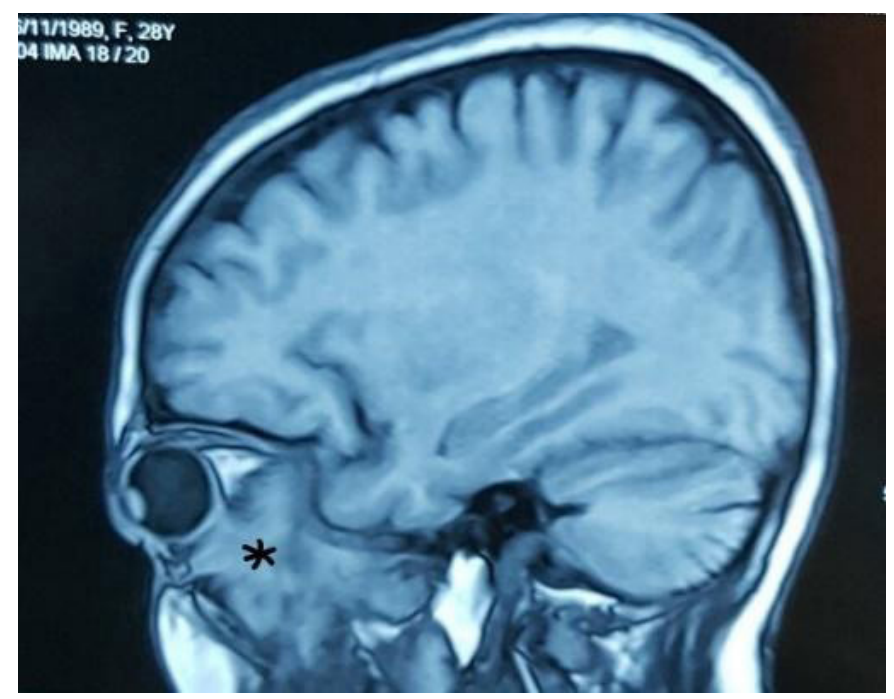

Figure 4: Sinonasal carcinoma invading the orbit (marked with * and arrow)

\section{DISCUSSION}

Malignant ocular tumors do not spare any age group. The youngest patient was a one month old child with RB and the oldest one was a 84 years old female with conjunctival squamous cell carcinoma. The mean age of our patient was $30.35 \pm 26.63$ years. Habib et al. (2019) et al in their study on ocular malignancy in Nigeria, reported the patient's age range from 6 months to 70 years. The average age of presentation in various researches ranged from 13 to 56 years (Habib et al, 2019; Kumar et al, 2009; Thakur et al, 2008; Poombejara et al, 2009).

There was a slight male propensity of $57 \%$ in our study which was similar to other reports (Poombejara et al, 2009; Lee et al, 2000; Habib et al, 2019). This could be because of the more health seeking behavior in males in our society.
Some ocular malignancies can be bilateral because their etiology is either germ line mutation in hereditary RB or sunlight exposure in OSSN or they are a part of systemic metastasis to the eye from distant sites like breast and lung cancer. Out of 106 patients in our study, $11(10 \%)$ had eye cancer in both the eyes simultaneously. Among them, nine were RB patients, one was OSSN with Xeroderma Pigmentosum and one was a patient of Leukemia. Bilateralism was also reported by Habib et al (2019) in 18\% and Thakur et al (2008) in 5\% of their cases.

As mentioned earlier, tumors can arise from almost any part of the eye and orbit. In this study, intraocular structures like retina and choroid are the most common sites seen in 56 eyes, followed by conjunctiva in 38 eyes and orbital content in 13 eyes. Lee in 2000 also reported retina in $54 \%$ as the most common site, followed by conjunctiva in $13 \%$ and orbit in $9 \%$. Similarly, 
Poombejara et al. (2009) reported conjunctiva (36\%), eyelid (28\%), lacrimal gland (14\%) and eyeballs $(10 \%)$ as the common sites involved.

According to the site of the lesion, clinical features also vary. In our study, red eye and visible mass were the most common complaints of the patients because visible mass can be a feature of OSSN, orbital RB or lid tumor. OSSN was the second common tumor (31.62\% eyes) seen in our study where the conjunctival tumor appears fleshy limbal mass in inter palpebral bulbar conjunctiva. Red eye as a mode of presentation was also due to the $\mathrm{RB}$ patients presenting in an inflammatory stage. It was followed by leukocoria as the second common mode of presentation at $18.94 \%$.
Poombejara et al. (2009) aalso reports the most common presentation of ocular malignancy being visible mass (44.6\%), followed by proptosis (10.8\%), and ulcer (9.6\%).

$\mathrm{RB}$ has been found to be the most common primary intraocular malignancy in childhood as well as the most common cancer of the eye and orbit together, accounting for $38 \%$ of our cases. Most of the studies in literature also state the same as shown in Table 5. The worldwide incidence of RB is one in 15000 to 20000 live births (Shields and Shields, 2004).However it is one of the most important tumors managed by an ocular oncologist because mortality can reach $99 \%$ if not treated.

Table 5: Comparison of relative frequencies of malignant ocular tumors types in Nepal with other parts of the world.

\begin{tabular}{|c|c|c|c|c|c|c|}
\hline $\begin{array}{l}\text { Current study } \\
\text { (Nepal) }\end{array}$ & $\begin{array}{c}\text { Kumar, } \\
2009 \\
\text { (Nepal) }\end{array}$ & $\begin{array}{l}\text { Gupta, } \\
2017 \\
\text { (India) }\end{array}$ & $\begin{array}{c}\text { Khan, } 2017 \\
\text { (Pakistan) }\end{array}$ & $\begin{array}{c}\text { Lee, } \\
2000 \\
\text { (Singapore) }\end{array}$ & $\begin{array}{c}\text { Domingo, } \\
2015 \\
\text { (Philippines) }\end{array}$ & $\begin{array}{c}\text { Habib, } \\
2019 \\
\text { (Nigeria) }\end{array}$ \\
\hline $\mathrm{RB}(38 \%)$ & $\begin{array}{l}\text { Sq cell } \\
\mathrm{Ca} 66 \%)\end{array}$ & $\mathrm{RB}(40 \%)$ & RB (44\%) & $\mathrm{RB}(54 \%)$ & RB (90\%) & $\mathrm{RB}(57 \%)$ \\
\hline OSSN $(32 \%)$ & $\begin{array}{l}\text { BCC } \\
(10 \%)\end{array}$ & $\begin{array}{l}\text { Seb gland } \\
\mathrm{Ca}(19 \%)\end{array}$ & $\begin{array}{l}\text { Sq cell Ca } \\
(16 \%)\end{array}$ & $\begin{array}{l}\text { Uveal } \\
\text { melanoma } \\
(19 \%)\end{array}$ & $\begin{array}{l}\text { Uveal } \\
\text { melanoma } \\
(8 \%)\end{array}$ & $\begin{array}{l}\text { Sq cell Ca } \\
(16 \%)\end{array}$ \\
\hline $\begin{array}{l}\text { Metastasis and } \\
\text { secondaries } \\
(11 \%)\end{array}$ & $\begin{array}{l}\text { Seb } \\
\text { gland } \\
\mathrm{Ca}(10 \%)\end{array}$ & $\begin{array}{l}\text { Sq cell Ca } \\
(10 \%)\end{array}$ & $\begin{array}{l}\text { Lacrimal } \\
\text { gland } \mathrm{Ca} \\
(9 \%)\end{array}$ & $\begin{array}{l}\text { Sq cell Ca } \\
(11 \%)\end{array}$ & $\begin{array}{l}\text { Metastasis } \\
(1 \%)\end{array}$ & $\mathrm{BCC}(3 \%)$ \\
\hline $\begin{array}{l}\text { Uveal } \\
\text { melanoma } \\
(9 \%)\end{array}$ & $\mathrm{RB}(7 \%)$ & & & & & \\
\hline
\end{tabular}


Choroidal melanoma is the most common primary intraocular malignancy of adulthood where nearly 6 out of 1 million Americans suffer from Choroidal melanoma (Denniston et al, 2009). The incidence is lesser in Asian population. In our study, it constituted $9 \%$ of the total cases only. OSSN is currently the preferred term for premalignant and malignant epithelial lesions of cornea and conjunctiva (Kaan, 2008). It accounts for $39 \%$ of all premalignant and malignant lesions of the conjunctiva and for $4 \%$ of all conjunctival lesions. Honavar (2015); Kumar and Poombejara (2009) also reported OSSN as the most common tumor of conjunctiva in $65 \%$ and $84 \%$ respectively. In the current study OSSN is found to be the second most common ocular malignancy seen in $32 \%$ of total cases.

Malignant eyelid tumors were quite common ranging from $10-22 \%$ of their cases in studies done by Kumar et al. (2009), Gupta et al. (2017) and Thakur et al. (2008). However, in our study it constituted 5.12\% only. Small eyelid tumors are usually locally managed by oculoplastic surgeons and general ophthalmologists as well; therefore referral to tertiary care centers like ours is reserved to recurrent and locally invasive cases only.

According to Abramson et al. (2003), neoplasms account for around $20 \%$ to $25 \%$ of orbital disease, mostly in elderly. In our study, orbital malignant conditions constituted 13 (11.11\%) of patients. Three cases were adenoid cystic carcinoma of the lacrimal gland which is also the most common lacrimal gland malignancy worldwide; while the rest of the 10 cases were distant metastasis and local invasion to orbit from the paranasal sinus and eyelid. However, Domingo (2015) and Koopman et al. (2011) reported lymphoma to be the most common malignancy of orbit. It was followed by adenoid cystic carcinoma of the lacrimal gland. Abramson in 2003 also stated that patients presenting with proptosis, globe displacement, pain and increased retropulsion should be suspected of having orbital tumors, either benign or malignant. We had $9 \%$ of patients presenting with proptosis and pain in $7.58 \%$ cases, though pain can be due to other ocular tumors as well. Incision biopsy for diagnosis of orbital tumors are rarely performed nowadays with the availability of imaging like CT scan and MRI, which gives the consistency and anatomical location of the tumor thus narrowing the differential diagnosis. In our study also, only two patients $(1.71 \%)$ underwent incision biopsy while the rest of the orbital tumors were diagnosed by imaging alone.

In our study, $11.11 \%$ of eyes had metastasis from distant sites and secondary invasion from neighboring structures like paranasal sinuses. It gives the message that the treating ophthalmologist should be aware of the fact that the lesion in the eye and orbit could be due to life threatening distant metastasis. This number is high in comparison to other studies mentioned in Table 5. Khan et al. (2017) and Domingo et al. (2015) both reported only 1\% of 
their patients having metastasis to the eye and orbit. Higher numbers in the current study may be due to the fact that cancer hospitals in Nepal do not have ocular oncology clinics yet, so the patients are referred to tertiary eye hospital like ours.

Most of the ocular malignancies were managed by surgery $(64.95 \%)$ in the form of excision of tumor, enucleation or exenteration. As described in Table 3, many patients also received a combination therapy of surgery, chemotherapy and radiation therapy as appropriate after consultation with an oncologist.

\section{CONCLUSION}

Malignant ocular lesions present as a diverse group of disorders with varied presenting features and location in the eye and orbit.
Retinoblastoma is the most common ocular malignancy in children and OSSN is the most common in adults. Choroidal melanoma is quite rare in this part of the world. In view of its sight as well as life threatening consequences, malignancy should be kept in mind in the differential diagnosis of unusual cases. Orbitoocular tumors can be diagnosed clinically and with imaging with a high degree of accuracy without the need of incision biopsy in most cases which is beneficial to initiate treatment without an invasive test.

However, final diagnosis is always made after the histopathological examination.

\section{REFERENCES}

Abramson DH, Dunkel IJ, Mccormick B, Dolphin KW (2003). Adult Ophthalmic Oncology: Orbital Diseases. In: Kufe Dw, P. R., Weichselbaum Rr, et al (eds.) Holland-Frei Cancer Medicine. 6th edition ed.: Hamilton (ON): BC Decker.ch.85.

Domingo RED, Manganip LE, Castro RM (2015). Tumors of the eye and ocular adnexa at the Philippine Eye Research Institute: A 10-year review. Clinical ophthalmology (Auckland, N.Z.);9:1239-47. doi: 10.2147/OPTH.S87308

Gündüz K, Esmaeli B (2008). Diagnosis and management of malignant tumors of the eyelid, conjunctiva and orbit. Expert Review of Ophthalmology;3(1):63-75. doi: 10.1586/17469899.3.1.63

Gupta Y, Gahine R, Hussain N, Memon MJ (2017). Clinico-Pathological Spectrum of Ophthalmic Lesions: An Experience in a Tertiary Care Hospital of Central India. J Clin Diagn Res;11(1):Ec09-ec13. doi: 10.7860/ jedr/2017/23589.9230

Habib SG, Lawan A, Victoria P (2019). Clinicopathologic presentation of malignant orbito-ocular tumors in Kano, Nigeria: A prospective multicenter study. Annals of African medicine;18(2):86-91. doi: 10.4103/aam.aam_37_18

Honavar S, Manjandavida F (2015). Tumors of the ocular surface: A review. Indian J Ophthalmol;63(3):187-203. doi: $10.4103 / 0301-4738.156912$ 
Kaliki S, Bothra N, Bejjanki KM, Nayak A, Ramappa G, Mohamed A, et al (2019). Malignant Eyelid Tumors in India: A Study of 536 Asian Indian Patients. Ocular Oncology and Pathology;5(3):210-9. doi: 10.1159/000491549

Khan AA, Sarwar S, Sadiq MAA, Ahmad I, Tariq N, Sibghat Ul (2017). Analysis of orbital malignancies presenting in a tertiary care hospital in Pakistan. Pakistan Journal of Medical Science;33(1):70-4. doi: 10.12669/pjms.331.12073

King, B. A., Rosenberger, E. U., Morales-Tirado, V. M. \& Wilson, M. W (2018). Uveal metastases in the midsoutheastern United States: a single-institution experience. Clin Ophthalmo; 12:1459-1463. doi: 10.2147/opth. S172464

Koopman, J. H., Van Der Heiden-Van Der Loo, M., Van Dijk MR, Bijlsma WR (2011). Incidence of primary malignant orbital tumours in the Netherlands. Eye (Lond); 25(4):461-5. doi: 10.1038/eye.2011.9

Kumar, R., Sharma, M. K., Pokharel DR, Gautam N (2009). Pattern of Ocular Malignant Tumors in Bhairahwa, Nepal. The Internet Journal of Ophthalmology and Visual Science, 7

Lee, S. B., Au Eong, K. G., Saw, S. M., Chan TK, LeeHP (2000). Eye cancer incidence in Singapore. Br J Ophthalm; 84(7):767-70. doi: 10.1136/bjo.84.7.767

Margo CE, Waltz K (1993). Basal cell carcinoma of the eyelid and periocular skin. Surv Ophthalmo; 38(2):169-92. doi: 10.1016/0039-6257(93)90100-1

Murray, A. K. O. D. P. I. (2009). Oxford Handbook of Ophthalmology, Oxford University Press.

Pombejara F, Tulvatana W, Pungpapong K (2010). Malignant tumors of the eye and ocular adnexa in Thailand: a sixyear review at King Chulalongkorn Memorial Hospital. Asian biomedicine; 3:551-555. doi: 10.5372/1160

Shields CL, Shields JA (2004). Diagnosis and management of retinoblastoma. Cancer Contro; 11(5):317-27. doi: $10.1177 / 107327480401100506$

Sunderraj P (1991). Malignant tumours of the eye and adnexa. Indian J Ophthalmol; 39(1):6-8.

Thakur SK, Sah SP, Lakhey M, Badhu BP (2003). Primary malignant tumours of eye and adnexa in Eastern Nepal. Clin Exp Ophthalmol;31(5):415-7. doi: 10.1046/j.1442-9071.2003.00688 